\title{
'No sex under my roof': Teenage sexuality in the USA and in the Netherlands since the 1880s
}

\author{
Cas WOUTERS \\ Utrecht University, Holland \\ c.wouters@uu.nl
}

Recibido: 10-09-2012

Aceptado: 19-12-2012

\begin{abstract}
The oneliner 'No sex under my roof' is used to reinforce the rule of premarital abstinence of sexuality until teenage children marry or move from home. In the USA, most parents still stick to this norm, whereas in the Netherlands since the late 1960s, a new rule developed, allowing teenage children to have sex, provided they 'feel strongly for each other' and feel 'ready' for it. This paper describes and compares developments in the USA and in the Netherlands since the 1880s, focusing on the social regulation of teenage sexuality, and based mainly upon such sources as reference books and sexology studies. The paper proposes an explanation of the two trajectories from national differences in the functioning of good societies, particularly in the regulation of social competition and social mobility. The rise in the USA of a highly competitive dating system and a complicated sexual morality indicates a smaller decline of power differences between classes, genders and generations, which partly explains the persistence of the old rule. Further explanation is found in America's lower level of social integration and more open competition between various centres of power and good societies.

The build up to the rise of a new rule among Dutch parents was an informalization of 'getting engaged', the diffusion of verkering (going steady) and of parental policies to stay 'in the scene', indicating higher levels of social integration and larger declines of power differences between classes, genders and generations. Yet, the long preservation of a homogeneous good society created a widening gap between a facade of decency and backstage realities. When this gap was washed away in the 1960s Expressive and Sexual Revolutions, it also washed away the old rule, and increasing numbers of parents allowed their teenagers openly to have sex, even at home.
\end{abstract}

Key words: teenage sexuality, status competition, USA, Netherlands, informalization

\section{Referencia normalizada}

Wouters, C. (2013). “'No sex under my roof': Teenage sexuality in the USA and in the Netherlands since the 1880s”. Política y Sociedad, Vol.50 Núm 2: 421-452

Sumario: Introduction: The road to touching and holding and kissing 1.Theoretical points of departure: Balances. 2.Courting in the USA. 3.The American dating system. 4.The social legacy of the dating system: the initial lead lost. 5.Meanwhile in Europe... 6.The Netherlands of Europe. 7.A theoretical view on manners books and the functions of 'good society'. 8.Explaining nationally different trajectories in regulating teenage sexuality. 9.Concluding remarks. 


\section{Introduction: The road to touching and holding and kissing}

In nineteenth-century good societies of Europe and the USA, the dominant code regulating admittance on the road to touch, hold and kiss was very similar. It demanded that young people first had to commit themselves to an engagement, a ceremonial public commitment to be married. Only marriage opened the door to further physical intimacies. Chaperones functioned to rule out earlier corporality. Young people could get acquainted at particular social gatherings such as dinners, parties and balls, most of them given in the drawing rooms of their parents or others within the networks of good society. The young man was advised not to dance more than twice with the same girl, for if he did, one would suppose he had 'eyes for her', thus arousing expectations and, therefore, obligations. If a young man did want to get to know her better than was possible in the ballroom, he should:

go to the girl's parents and ask them personally for permission to pay them a visit. If the parents are not present at the ball, you ask the girl and inquire about her mother's 'day at home'. Nevertheless, you should still ask her parents to be received, and pay the visit within two weeks after the ball. If your person is appreciated, they will ask you to come again and not wait too long before inviting you. (ECvdM 1911: 106/7)

When he called, he was received in the drawing room, parlour or, in the USA, on the porch. In each case, someone else would be present or within hearing distance. The young man could be invited to call again, or not, and he could, of course, decline the invitation. But if his calling was continued, these visits were expected to culminate in his proposal of marriage: 'If after a reasonable time no proposal of marriage is made, it would be well to let the friendship pass with the melting of the winter snows or the falling of the autumn leaves, according to the season' (Wade 1924: 116). These descriptions clearly bring out the large distance the sexes were expected to keep between them, and also how every step towards diminishing that distance was at the centre of the public eye and well guarded by the girl's parents and family.

If a proposal did follow and she and her parents would accept it, the couple would first become 'engaged' to be married. An 'engagement' also served the couple to get to know each other better. And although sexual experimenting was explicitly excluded, it was more or less accepted and expected that at least some sexual intimacies would occur. Therefore, good manners and her reputation demanded that it would be the young woman who breaks off the engagement. A man who did this was described as a boor, so 'the only thing he could do was to provoke her into breaking off the engagement (ECvdM 1911: 114). Because it was generally expected that most couples would 'fall' and give in to temptation if given the opportunity, the respectable couple, even when engaged, would not be left alone much; that would damage their reputation. Such was the prevailing courting regime. Its main location was the drawing room.

Then, from the end of the nineteenth century onwards: 
in all of social life, in fact there was beginning to be provision for respectable women to meet in public places outside their own homes. Cafés, the growth of tea rooms, the use of buses, even the provision of public lavatories for women, were as important in freeing middle-class women from strict social ritual as the slow erosion of chaperonage. Contact by telephone and the later mobility that came with cars began to undermine the most formal parts of etiquette. (Davidoff 1973: 67)

The historian Porter adds the importance of 'the coming of the bicycle and women taking up more sports' (1972: 81). Coeducation also played its part. By and large, 'alternative models of femininity - the university woman or even the suffragette offered "careers" that competed with some success against fashionable Society' (Curtin 1987: 243-4).

Up to World War II, in Europe and the USA, trends went in the same direction of emancipation of younger generations and their sexuality as well as of emancipation of women and their sexuality. Both courting relationships and engagements increasingly came to be charged with sexuality. More specifically, the process was towards greater freedom to control the dynamics of one's own relationships, whether romantic or not, and to decide about the respectability of meeting places and conditions. In the USA, this emancipation developed via the dating system, established in the 1920s, in Europe via an informalization of (formal) engagements and a rise of verkering or 'going steady'. After WW II, national differences declined, although the social legacies of the two different trajectories are still quite noticeable. In this context, this paper raises the question of differences in the national regulation of teenage sexuality: why is the rule that American parents should demand abstinence of full sexuality of their teenage children until they move from home still dominant in the USA, and why have the Dutch departed from this rule, particularly since the end of the 1960s, by allowing pre-marital sexuality?

The American sociologist Amy Schalet initiated the comparison of differences in the regulation of teenage sexuality between the USA and the Netherlands by raising the question why most Dutch parents would conditionally allow their teenagers to have sex 'under their roof', whereas most American parents would never allow this $(1994,2011)$. Until the early 1970s, however, most Dutch parents would also prohibit this and even use the same expression 'not under my roof'. Therefore, this article develops a wider historical explanation of these national differences. It builds on my studies 'Sex and Manners' (2004) and 'Informalization' (2007) by integrating new material to the social history of getting engaged and to the long preservation of a homogeneous establishment in the Netherlands. This material made me emphasize the significance of American upper classes losing a cultural battle to the middle classes and to peer-groups. Direct confrontation and comparison of the two countries thus highlights how differences in the social regulation of teenage sexuality are connected to the regulation of social competition and mobility. 
After presenting a few theoretical points of departure in the next section, I will describe and compare the two national trajectories and their present-day social legacy. The final sections aim at an interpretation of the two developments.

\section{Theoretical points of departure: Balances}

My toolkit for historical and international comparisons contains a number of yardsticks, conceptualized as balances that are universal in the sense that they can be fruitfully applied in various countries and different periods. Together, they open a window on a society's level of differentiation and integration, on the length and density of their networks of interdependencies. Here, I restrict myself to mentioning the most relevant ones for this article. ${ }^{1}$

The first balance is the balance of power. As individuals grow up they become less dependent upon their parents, and it is a generally accepted fact that this shift has also occurred over the generations: throughout the twentieth century, parents increasingly took more of their sons' and daughters' needs and longings into account. Thus, twentieth-century changes in the prevailing code of courting and sexuality reflect changes in the balances of power between the generations and the sexes.

A second balance is the balance of controls: between external social controls and internal ones or self-controls. Throughout the twentieth century, this balance has continued shifting from an emphasis on external controls to an emphasis on selfcontrols. In getting rid of chaperones, for example, women had to become their own chaperone and to do their own courting. They came to navigate under their own steam and as they came to be expected and obliged to do so, social controls increasingly came to be focused on self-controls. This trend was reinforced in many ways, for example by the rise of affluence and its spread via welfare state arrangements. These triggered a decline in the societal level of mutual suspicion and fear, and a rise in the level of mutual trust, or, formulated in terms of the balance of controls, a rise in the level of mutually expected self-controls. 'Individuals are compelled to regulate their conduct in an increasingly differentiated, more even and more stable manner (Elias 2012: 406).

A third balance is that of formalization and informalization. Historically, the long-term process of formalizing manners (and disciplining people) in 'the West'

${ }^{1}$ Other balances are the balance of involvement and detachment, the we-I balance, and the balance of competition and cooperation: the extent to which there is competition in cooperation and/or cooperation in competition. As a rule, this balance is closely related to the balance of work and play: how much work is integrated in play and how much play in work. Both open a window on the level of differentiation and integration within networks of interdependencies. 
refers to the subjection of more and more aspects of behaviour to increasingly strict and detailed regulations, partly formalized as laws and partly as manners. Informalization refers to a trend that became dominant from the late nineteenth century onwards, a trend towards a widening range of socially accepted behavioural and emotional alternatives, a change from fixed rules to flexible guidelines, depending on the various types of situation and relation. This widening range of options went hand in hand with increasingly careful scrutiny of the choices made, triggering not only greater flexibility and reflexivity but also an 'emancipation of emotions', which included an emancipation of sexuality, a sexualization process.

The last balance to be mentioned is the lust-balance: between the longing for sexual gratification and the longing for enduring intimacy, between sex and love. In the good societies of Europe and the USA, from the last decades of the nineteenth century onwards, the traditional lust-balance of a lust dominated sexuality for men and a complementary (romantic) love- or relationship-dominated sexuality for women has been shifting in the direction of a 'sexualization of love' and an 'eroticization of sex', provoking new and more varied answers to the lust-balance question: when or within what kinds of relationship(s) are (what kinds of) eroticism and sexuality allowed and desired?

\section{Courting in the USA}

From the 1880s until the 1920s, courting manners generally showed the same overall development: young people started to date, that is, to go out together, both with and without a chaperon. Full surveillance via chaperones was eroding as was the system of 'calling', he visiting her at her parents' home. By the mid-1920s, advice on dating, necking and petting, the 'line', the stag line, cutting in, and getting stuck had appeared in most American manners books and only in American books, signalling the establishment of the American 'dating system'. It was backed up by a youth code that openly contradicted the old formal adult code of 'calling' in which chaperoned encounters prepared for an engagement and then marriage.

American upper classes as well as their European counter parts were more strongly motivated to safeguard their daughters from meeting 'unsuitable candidates' than middle classes, which explains why the old more formal adult code was longer preserved in their circles. Within the spectrum of manners books, authors such as Emily Post and Amy Vanderbilt represented this upper class formal (adult) code. The American Edmund Wilson has contrasted Lilian Eichler, the author of a 1920s successful manners book, to Mrs Post. Eichler, he wrote, 'makes social life sound easy and jolly', but Mrs Post seems 'to believe in the existence of a social Olympus' and 'always assumes that the reader wants to belong to Society' (Wilson 1962: 382). This traditional upper class orientation explains why Emily Post ignored 'petting' in her first editions of the 1920s, and why, in her 1931-edition she declared the topic 
to be 'quite outside the subject of etiquette - so far outside that it has no more place in distinguished society than any other actions that are cheap, promiscuous, or vulgar' (Post 1931: 297). In short, Mrs Post ignored the rise and establishment of the dating system.

Mrs Post also remained ambivalently conservative about the decline of chaperonage. In the 1937 edition of her book, one side of her ambivalence is represented by writing: 'from an ethical standpoint, the only chaperon worth having in this present day is a young girl's own efficiency in chaperoning herself'. The other side of her ambivalence disregards this change from protection by chaperonage to self-protection by training. On this side she sticks to the necessity of chaperones because 'there still remain appearances to be considered' (1937: 353-4). In the same breath, she questions the capacity of any young girl to protect herself:

And yet - any attempt to apply the rules of propriety to a young woman's going alone to the apartment of a man, would be the same as to attempt to give directions for applying a flame to a high explosive... that is, granting a certain element of attraction between the woman and the man. (1937: 358)

In sum, Mrs Post thought that the chaperon had to remain in function for two reasons: first to accommodate Mrs. Grundy - her personification of blame gossip and other forms of external social control - and second, for lack of trust in the strength of self-control. Her ambivalence about the chaperon lasted into the 1940s.

The 1960 edition of Post's manners book no longer contained the section that casts doubt on the young girl's capacity to protect and restrain herself when alone with a man. In the 1952 and 1963 editions of Amy Vanderbilt's famous etiquette book, however, this very conviction was expressed for engaged couples:

If young people didn't want to make love most of the time during the period of their engagement it wouldn't seem normal. ... For engaged people of all ages, society expects chaperonage of a kind. They may, of course, spend long days and evenings together alone, but they may not go off for a weekend or overnight unless adequately chaperoned. (1952: 126; 1963: 13)

These references to 'engaged people of all ages' were the last exceptions to the increasingly established rule that the words chaperone and chaperonage referred to children, no longer marking the transition from teenager to adult, but that from child to teenager or adolescent.

Whereas Post and Vanderbilt represented the formal (adult) code, many more authors represented the more informal and more middle class youth code by discussing the dating system and its inherent petting. One author straightforwardly contradicted Mrs Post in a book addressing girls, who as newcomers to the college campus are 'still an adventure to the men':

So, of course, you want to make the most of your novelty. With skill, you can build lasting popularity for yourself for the rest of your four college years on campus. If you date often, you will have many opportunities to 'neck,' in spite of Emily Post's claim that petting has no place in polite society. (College men, apparently, have never read her book.) ... All of them are frankly curious to discover if you are a 'hot 
number' or a 'cold proposition.' That you must determine for yourself... (Eldridge 1936: 176)

Here, Post is ridiculed for her upper-class lack of any (middle class peer group) street sense. It expresses the feeling of being liberated from upper class rigidity. The experience of winning a class and status struggle by establishing the dating system helps explain why this system became such a proud national symbol of freedom.

\section{The American dating system}

In her study of this system, Beth Bailey assumes a period of transition, in which a boy might have come on a 'call', expecting to be received in her family's parlor, while 'she had her hat on', expecting a 'date', that is, to be taken 'out' somewhere and entertained in some public place or commercial amusement. In the USA, together with the word 'date', a whole family of words and practices entered youth culture and were developed further. Dating codes became elaborate enough to speak of a dating system. By the mid-1920s, dating had almost completely replaced the old system of calling.

The appearance of the dating system signifies the escape of young people from under parental wings and the formation of a relatively autonomous courting regime of their own. This regime was a novelty in the history of the relationship between the sexes, and it lead to a head start in the emancipation of sexuality and to the first youth culture - restricted to the USA in contrast to the youth culture of the 1960s, which was a western international one. The sociogenesis of the dating system can be sketched with the following six uniquely American characteristics.

1) Youth culture and dating developed on coeducational colleges and campuses: these uniquely American villages of the young allowed for an emancipation of young people from under the wings of their parents. In the 1920s, when two thirds of all students were at coeducational residential colleges, they were able to make their own code of courting behaviour in generational solidarity against older generations. In her study of these developments, Paula Fass shows how 'the young were more and more orienting their behaviour to nontraditional institutions - peers rather than parents, movies rather than the local community' (1977: 290).

Negotiations between the generations also produced new appearances to be kept up: 'All colleges of good repute now insist on a list of patronesses who will give their presence as well as their names to the fraternity dances, as a guarantee that these amusements will be conducted with the decorum of the private ball' (Wade 1924: 272). And: 'Colleges will not allow a house party to be insufficiently chaperoned, and no doubt several women of standing in the community will act as sponsors' (Pierce 1937: 18). The young, however, developed 
many ways of escaping from their supervision: 'Chaperones were invited but conveniently seated in the parlor, superficially engaged in conversation (often the chore of the freshmen), and kept out of sight and hearing of the real activity on the dance floors, entertainment areas, and unlit grounds outside' (Fass 1977: 196). Thus, escaping supervision could become an erotic and sexual ingredient of courting.

2) Sex quickly became the key issue in the emancipation struggle of young people. By the 1920s, the question 'how far to go' beyond kissing was openly debated and debates soon centered on the practices of necking and petting. The compromise was a youth code that allowed for some sexual activity but explicitly not 'going all the way'. In this sense, dating was oriented toward sex and marriage. If college youth would adhere to the adult code by saving 'going all the way' for marriage, their years of living by the youth code would remain without significant long-term risk, for the campus community was temporary and separate - a condition that favoured peer-group pressure. Under this pressure, petting soon turned into a necessary demonstration of conformity. 'Experimental erotic exploration was often a group phenomenon,' writes Paula Fass. 'The petting party', she concludes, 'both forced erotic exploration and controlled the goal of eroticism' (Fass 1977: 266).

3) Getting to know numerous partners was defended as a good preparation for selecting a marriage partner later. A date developed into sort of a dalliance relationship for the duration of the date and without further commitment. Accordingly, the pair relationship of a date was not exclusive: as the dating system developed, 'date a dozen' - having numerous partners - was encouraged while 'going steady' was discouraged and rejected as a practice of cowards without the guts to 'shop around'. Dating a dozen gave rise to an institution called the 'line', a well-rehearsed and oft-repeated set of phrases used in initial contacts between the sexes to flatter and charm: 'Instead of a mere "you look nice tonight", you might say in a profoundly stirred baritone, "That shade of blue does things to your eyes"، (Jonathan 1938: 98-9). Indeed, 'A certain amount of exaggeration is customary between boys and girls' (McGinnis 1968: 100). In dating, as in all types of negotiating, the American fierceness of relatively open competition triggered and allowed for exaggerations, boasting and using superlatives.

After World War II, when 'going steady' nevertheless became popular among American teenagers, this popularity did not affect the dating system much. By then, the system had become such a firmly rooted social institution that 'going steady' was seen as temporary: the young were 'going in and out of dating'. Thus, 'going steady' was integrated in the dating system.

4) On dates, as boys would expect some necking or petting, girls had to learn 'how to meet the "jazz age" halfway, without destroying any of the old family standards' (Schlesinger 1946: 54). This was the middle ground of the goodbad girl, the one that reminded Margaret Mead of a couplet of the early 
twenties: 'Won't somebody give me some good advice on how to be naughty and still be nice?' Mead convincingly showed, that during the dating period, 'there is the imperative that one ought to be able to play with sex all the time, and win. The younger the boy and girl when they learn to play this game of partially incomplete, highly controlled indulgence of impulse, the more perfectly they can learn it' (1950: 290-1) This imperative stimulated increasing subtlety in the art of steering 'between the rocks of prudery and coquetry' (Hemphill 1999: 110), for in order to 'remain the winner, she must make the nicest discriminations between yielding and rigidity' (Gorer 1948: 116).

5) The rise of the dating system implies that the authority of parents over their daughters' courting was placed into the hands of young men. As the control over youth by the older generation declined, young men will have dominated the constitutive process of dating codes. With the money they spent on a date, boys purchased obligation, their money purchased inequality, it purchased control: 'the more money the man spent, the more petting the woman owed him', and “'nice girls” cost a lot' (Bailey 1988: 81, 23). Dutch treats (paying your own way) were vigorously rejected. Boys came to be the host of girls, boys paid; they took the initiative and assumed the control that came with that position.

Boys were expected to make sexual advances and their attitude is captured in a 1920s fraternity phrase: 'If a girl doesn't pet, a man can figure he didn't rush her right' (Stearns and Knapp 1992: 786). The responsibility for sexual restraint was put in the hands of women: boys could blame the girl for all sexual acts, even if unsanctioned or uncalled for: either she had not set limits (in time) or she was not truly virtuous. Thus, that old acquiescent idea that 'boys will be boys', that they would 'naturally' want some sexual activity, and would 'go for it', was accepted and reinforced. This instrumental attitude to women was formalized in the dating system. College behaviour of the twenties filtered down to high schools by the 1930s, and 'at least by the early 1940s, middle-class boys talked in terms of pushing petting as far as their dates would allow, if not farther, describing the whole experience as "having fun" or "taking them for a ride" " (Stearns and Knapp 1992: 786).

6) Each date and each person dated counted and was rated in a popularity contest. As a social contest for popularity, dating produced a peculiar mixture of competitive conformity. In the 1930s, dating became a competitive quest of thrill and increasingly more sexed, necking and petting becoming controlled rituals of restrained promiscuous sexual exploration. Courtship practices had stimulated a 'thrill-seeking behaviour' that turned courtship into 'an amusement and a release of organic tensions', and kissing into an activity that 
'may imply no commitment of the total personality whatsoever' (Waller 1937: 728). In their peer groups a young woman was 'valued by the level of consumption she could demand (how much she was "worth"), and the man by the level of consumption he could provide' (Bailey 1988: 58). Dating became a 'competitive activity dominated by money and consumer one-upmanship' (Caldwell 1999: 229), materialized also in the popular taxi-dance halls, where all sorts of men (with the exception of 'American Negroes') could find access to young women and girls at 'a dime a dance' (Cressey 1932: 3). ${ }^{2}$

The peer pressure to conform in the competition for popularity implied that you had to rate in order to date, and to date in order to rate. This competition turned dating into 'an emotionally inhibiting cat-andmouse game of staged seductions and "scoring”" (Fass 1977: 271), a paying and petting competition that pushed all participants towards further exploration of the path of lust. The competitive, instrumental and commercial attitude that was institutionalized in the dating regime, was extended to 'rating and dating' (Waller 1937) just as it was extended to 'paying and petting', and ever since the 1960s to an expanding massive consumption of sex bought on a market. Another social legacy of 'paying and petting' is identified as 'raunch culture', featuring large numbers of 'female chauvinist pigs' (Levy 2005). Buying sex and exploring sex in rather volatile, commercial and instrumental relationships can be interpreted as continuations of forms of behaviour that were highly valued in the dating system. They suggest the continuation of a lust balance emphasizing the longing for sexual gratification more strongly than the longing for enduring intimacy.

\section{The social legacy of the dating system: the initial lead lost}

To understand this commercialisation of sex, that is, why American women allowed paying and petting to become connected, it seems important to compare the rise of the dating system as an American 'youth culture' with the second international youth culture of the 1960s. The latter was soon followed by a wave of emancipation of women from the control of men: in the late 1970s, the women's movement in all

${ }^{2}$ In his introduction to The Taxi-Dance Hall, Cressey wrote that between 1925 and 1932 it was becoming 'the dominant type of dance hall in the business centres of our largest cities'. 
western countries turned against sexual violence, that is, against male dominance. In the USA of the 1920s, however, liberation from the regime of older generations and their no-sex-at-all taboo was not followed by liberation of male sexual dominance and oppression. The US dating system, the paying and petting codes in particular can be interpreted as a consequence and as proof of this absence.

The gradual social acceptance of petting in the 1920s, but explicitly not of 'going all the way' (and condoms were illegal and hard to get), will have channelled sexual experimenting and sexual excitement equally gradually from breast fondling at first, towards masturbation (hand jobs) and oral sex (blow jobs) later. In the course of this transition, 'going all the way' will have become the main and then the only criterion among the young as to whether or not they lived up to the adult code. Living by both the youth code and by the adult code, was in fact living by a double standard regarding sex. The bridge between the two became known as 'technical virginity' and 'technical fidelity'.

When dating had become a firmly rooted social institution, a separate code for business situations developed. Around 1980, in the USA as well as in Europe, men came under attack for sexual harassment. Everywhere this implied that at work, making passes at someone in an inferior social position was tabooed, but in the USA virtually all flirting at work was branded as harassment. It created a gap between business manners - from which sex and sexuality were banned - and dating manners that centred on sex and sexuality. Thus, male dominance was institutionalized in a threefold double morality, the first between men and women, the second between (college) youngsters and adults, and a third one between men and women at work and when dating or on the 'second shift' of work at home (Hochschild 1989, 1997). In sum, the reputedly advanced greater freedom and independence of women in America seems to have been preserved at work, although at high costs, and to have eroded outside office hours.

These difficulties in the struggle for greater equality for women can be understood at least partly as a social legacy of the dating regime, in which the taken-for-granted male dominance of the 1910s and 1920s was formalized, integrated and internalized in dating codes and ideals, and more or less fossilized in subsequent years. This hardening may help explain why, in the second youth culture, when the emancipation from parental regimes was soon followed by a movement for female emancipation, the latter had harsher repercussions in the USA than in European countries. The persistence of this tradition demonstrates how firmly it is socially rooted, but also how strongly its underlying uneven balance of power between the sexes was internalized. This caused the traditional double morality to be and to remain stronger than in Europe and it helps explain why the reputedly advanced greater freedom and independence of women in America diminished (Wouters 2004).

Up to the twenty-first century, parental generations have demanded supervision and simultaneously showed little confidence in the capacity of the young to supervise themselves (Wouters 2004). In the 1990s, Amy Schalet found in her interview study, that American parents believed their offspring to be roused by 
raging hormones and therefore incapable of responsible loving relationships (1994, 2011). By demanding supervision parents provided youth with an alibi to escape supervision. In fact, they created a climate 'in which boys are likely to have their first sexual experience in situations where they are least able to be in control, behave rationally, or have an emotionally intimate experience: at parties and drunk' (Schalet 2003: 255). Thus they 'live up' to the image of youth sexuality as a mine field of 'raging hormones' and 'bubbling testosterone'.

In addition, parents allow their teens some 'space' to escape and 'sneak out', while they 'pretend not to know' by practicing the policy of 'don't ask, don't tell'. Here are a few examples of this policy towards daughters: 'Officially, Lisa, who is currently fifteen, is not allowed to date until she is sixteen. But Lisa has a boyfriend and she knows her parents know but they “just don't really say anything. They just let it slide, I guess”.' (Schalet 2011: 124) And Caroline said: 'They don't want to know that I'm doing it' (Schalet 2011: 113). The policy appears to be 'part of an overall strategy of hiding the sexual maturation of adolescent girls. The good girl that most girls seek to be, and most parents seek to raise, does not, it seems, have a sexual self' (Schalet 2003: 196). This is not unrelated, of course, to the USA having the highest percentage of teenage pregnancies in the West. Yet, 'on balance', Peter Stearns concluded, 'Americans decided to identify sex, rather than pregnancy, as the main problem when minors were concerned' (1999: 243).

The 'don't ask, don't tell' policy seems characteristic of a rather unequal balance of power and of external controls that provide parents as well as children with enough 'space' (and hypocrisy) to live up to the established rules, that is, nominally... until they reach the age of eighteen or go to college.

\section{Meanwhile in Europe...}

In European countries like England, Germany or the Netherlands, all the characteristics of the dating system were absent: there were no youth villages, no rating and dating, no paying and petting, hardly any peer pressure and no open competition in popularity or 'scoring'. And during the first half of the twentieth century, the possibilities of young and unmarried people to feel, touch and kiss hardly came up for discussion, certainly not as openly as in the USA. Yet, in the same decades as 'dating' spread and was established in the USA, the European trend towards increasing latitude in chaperonage and courting regimes involved rising social acceptance of a period of getting to know each other before an engagement. It was a period of 'friendships' and 'going steady', although the latter word was not used in manners books.

It was not used in German manners books because in discussing 'matters of the heart', authors generally restricted themselves to the basic rule of thumb to be open and honest. Courting was perceived as belonging to the private world behind public scenes where Goethe's maxim Erlaubt ist was gefällt (what pleases is permitted) prevails. 
In British Europe, rich and aristocratic families kept up chaperonage with greater strictness than did the middle classes: 'there was some hint that the "new woman" with her bicycle and athleticism was a product of the middle classes.' The upper classes lagged behind, because they were more strongly motivated 'to ensure she met only proper candidates' (Curtin 1987: 243). In this respect, they behaved like American upper classes.

English authors of manners books did discuss friendships springing up, but they did not discuss the rise of 'going steady' as a period before engagement. They remained rather vague and never specified whether or not kissing, touching and caressing are in or kept out of a friendship. These social and sexual opportunities and dangers remained veiled under the general warning 'to be very careful'. Indeed, this is 'typically English'. To understand why there was no other expression in these books than a blank 'friendship', a comparison with the Netherlands seems helpful, for the authors of Dutch manners books were somewhat more direct in these matters.

\section{The Netherlands of Europe}

In the Netherlands, the early twentieth century saw an erosion of chaperonage coinciding with the rise of possibilities for the young to meet beyond their parents' control. One author noted: 'The young girl used to be prostrated by the corset of convention. [Today, however,] she is no longer in her mother's shadow'. In contrast to English manners books and similar to American ones, this emancipation is related to co-education: 'When the daughter has completed school, where she often sat next to boys in the same classroom, she is an independent being' (ECvdM 1912: 266-68). Another author also writes that co-education generates 'a pleasant and enjoyable sphere between young girls and boys in our country, for the most part free from the slur of affectation and mannerism' (Viroflay 1916: 83-4). In England, not many schools had co-education and the great majority of those who had, were educating children less than twelve years of age. Above that age, boys of parents who could afford it would visit a 'public school'.

Dutch manners books provide some information on getting engaged. Early in the century, an author still noted that the traditional way of announcing an engagement consisted of the couple going for a walk together, but she added: 'nowadays this measure is outdated, for today young girls are no longer kept apart from young men as meticulously as before' (Rappard 1912: 73). Simultaneously, getting engaged was losing some of its certitude as a solemn or holy pledge to get married in due time. This was expressed already in the late nineteenth century, as for example in warnings against light-hearted 'beaux' and 'coquettes' with a history of broken engagements (A 1894: 27) and against too short engagements, because these could give reason 'to suspect the young man's motives' (Engelberts 1890: 78). The motives hinted at were to hold, kiss and touch, activities only an engagement officially allowed for. 


\subsection{Sexuality and an engagement: between becoming acquainted and marriage promise}

When engaged, a couple was expected to limit sexual explorations. However, authors were ambivalent; their advice made it clear that one should not go too far, but also that exactly this did happen: 'The complete expression of love, however, should be kept for the future husband. If the exchange of kisses during an engagement becomes too frequent, kissing in marriage will have lost its value.' Hence the ambivalent conclusion: 'Taking all this into consideration, it makes sense, if possible, not to leave the couple alone' (Staffe 1900s: 98). This ambivalence is reminiscent of Mrs Post, who for the same reasons decided against a young girl going to a man's apartment alone, and also of Amy Vanderbilt's command of the 1950s and early 1960s: 'For engaged people of all ages, society expects chaperonage of a kind.'

Another Dutch early twentieth-century advisory has it that, as fiancée, a girl should not allow any liberties that she would have been ashamed off before, and continued that she should show him 'that his presence is the most precious thing in the world for her and that there is nothing she would prefer above being united with him forever, but she should not go to lonely and secret places.' For 'the young man might rejoice this at first, but soon he will develop an aversion to it and his esteem for her will drop' (Seidler [1911-15]: 75). This is similar to American girls having to make the nicest discriminations between yielding and rigidity. The motive is also the same: save it for marriage. A big difference, of course, is that dating allows lust without love while an engagement doesn't.

In the late nineteenth century, authors begin to voice pragmatic resignation about the 'many engagements that are broken off again': an author advises against announcing an engagement too officially or to publically such as by announcing it in a newspaper. For the same reason, engagement receptions should be small and intimate, for the greater the style of the reception, 'the more ridiculous the people involved will become in the eyes of the world, when the bond is broken off again' (Woude 1898: 22, 25). In 1911, Madame Etiquette echoes earlier advise not to make too much fuss over an engagement, 'for if it breaks off, which happens quite often, then all those flowers and festivities will make the memory all the more sad' (ECvdM 1911: 188). In the early 1920s, increased caution is evident from the reason given for announcing an engagement by sending two separate cards: if the engagement is broken off, 'it is not pleasant that an engagement card is kept here and there or is left wandering about. Considering the number of engagements that are broken off, it is advisable not to send too many cards around' (Margaretha 1921: 118-19). 


\subsection{Speaking about engagements, silencing verkering}

In the 1920s and 1930s, the trend towards a more easy-going attitude towards engagements continued (Eggermont 1993: 111). Parents were removed further from the scene: now authors not only jeered at the 'startling unconcern' shown in getting engaged but they also complained about young men and women showing no respect to their parents by confronting them with the established fact of being engaged (Margaretha 1921: 29-30; Brummell \& Co 1927: 17). In this context the word verkering was first used to indicate the rise of an informal courting relationship, without fixed commitment or ceremonious pledge. The author who did so complains about a verkering developing into an engagement of which the couple abruptly confronts the parents with. Such a bond, she writes:

is usually preceded by a period of flirting and fooling about [scharrelen], and half the town or the whole village knows about it, except for the parents. Quite often such flirting and fooling about [scharrelpartij] do not even eventuate in a steady relationship [vaste verkeering]. And any girl who has experienced more than one such scharrelpartij is characteristically called in popular, not quite parliamentary, language: a 'licked roll' (or a 'town bicycle’). (Margaretha 1921: 143)

These words scharrelen and verkering are filled with condescension, and these practices were not discussed, yet this quotation suggests the practice had become established at the same time as dating had. And the term verkering had spread from about the same time as dating had in the USA, that is, from the 1880s onwards. Before the 1880s, the courting connotation of the term was absent; it had the more general meaning of being in contact with or in the company of one or more others. Examples and references in the Woordenboek Nederlandse Taal (Dutch equivalent of the Oxford English Dictionary) suggest that the word was used increasingly to denote a courtship relationship. If such a verkering lasted and the bond between the two would become more serious and stable, the relationship was developing into vaste verkering, which can be translated as 'going steady' because the word vast means 'steady'. Another similarity with dating is that the word and the practice were looked down upon by the upper classes and became popular among the middle classes, although secretly popular in the Netherlands. In contrast to dating, a couple with verkering was not expected to have similar relations at the side. This difference can be understood from the power advantage of a youth living in youth villages. The other similarities indicate that despite the differences between the USA and Europe, the emancipation of youth and their sexuality from under parental regimes saw roughly the same periodization.

The fact that only engagements were discussed, not verkering, implies that authors took side with the establishment and their formal code. They ignored the rise of an informal one, jeered at the 'startling unconcern' shown in getting engaged and extended their scorn to breaking engagements with similar freedom from care. One author declared it to be very incorrect for a young girl to tell her parents out of the blue that she was engaged, and adds: 'And yet, today, this happens all too often. 
There is a tendency today simply to eliminate the parents from these important life events and to take decisions into one's own hands. How shallow and wrong!' (Kloos-Reyneke van Stuwe 1927: 27). Another author observed a fading of the ritual procedure for getting engaged:

One person courts in a car, another on the beach, a third one seals the case with a kiss, a fourth person first kisses, proceeds courting the following day, and accomplishes an engagement within a week. The parents' consent has become a factor of third order. In certain prominent circles, consent isn't even asked for; parents are informed of the engagement only as sort of a 'notification'. The younger generation has progressed! (Brummell \& Co. 1927: 17)

In the 1930s, authors continued to target 'rash engagements' that oblige friends and relatives to buy presents and pay a visit, but that are easily and silently invalidated: “"Pim? Oh... didn't you know? That finished a long time ago!”' (Alsen 1936: 61; also Haeften 1936: 47). The popularity of courting relationships without being 'properly engaged' motivated this author to complain that, 'in recent years, a breakdown of moral consciousness has come about', for 'many young people would not be able at any moment to tell with certitude whether they are engaged or not; several also leave it to your discretion whether or not to call their relationship with someone of the opposite sex an engagement' (Alsen 1936: 60). These words signal that it had become accepted for a couple to present themselves as being engaged without having gone through the formality - they had verkering or 'vaste verkering' but called it verloving, an engagement. Both the authors of manners books and their audience avoided the term verkering.

\subsection{Staying in the scene: gedogen}

In the second half of the 1930s, parental control over the younger generation had softened to the point that 'wise parents' would not think of asking a young man for his 'intentions' when he paid a little extra attention to their daughter, 'not even if he were to take her out frequently'. They might talk about this amongst themselves, but 'usually they leave these things completely to the young people themselves' (Veen-Wijers 1936-40?: 93 also in 1946-50: 108). But parents certainly expected the couple would timely confide in them, not only in a late phase (Post 1938: 116). In view of such enlarged leeway, parents were advised to give freer rein to their adolescent children bit by bit, for if they were kept from availing themselves of the freedom now permitted too strictly and too persistently, 'they will escape from these restrictions anyway, and then run the risk of starting, in some dancing or other, totally condemnable affairs' (Paeuw 1934: 205).

These words harbour the motive for practicing a type of tolerance that spread in the Netherlands and became known as gedogen: the conditional allowing of a practice, usually combined with a policy of cautious determent. Gedogen enables those who tolerate a practice to stay 'in the scene' and prevent the practice from disappearing 'underground' and thus to maintain a controlling eye. The word 
gedogen dates back to the sixteenth century, when its meaning was closer to 'endure' and 'to put up with' than to 'tolerate' and 'allow', but both meanings were kept. Today, the best known examples of gedogen concern soft drugs, prostitution, and euthanasia, but the word is used also for parental practices in raising children.

After the Second World War, in the 1950s, it was observed that, due to the 'very free contacts' between young people, formal engagements had dropped in frequency. Increasingly, the phase was skipped, according to this author, because without being formally engaged, couples 'have all the freedom needed to come to a decision regarding the desirability of a marriage; they can have their intercourse as frequently and as intimately as they please' (Schrijver 1954: 43). Yet, through the 1950s until the late 1960s, many people still felt attracted enough to the tradition of getting engaged to keep it up.

\subsection{Sexuality in engagements, dating, and verkering}

In 1959, the sexual freedom that came with an engagement in the Netherlands was compared to the sexual freedom offered by the dating system in the USA. The comparison was made in an interview (Het Vaderland 15 August 1959) with George Simpson, Professor of Sociology at Brooklyn College, New York, on the occasion of his return to the USA after a year teaching at Leiden University. Simpson defended the dating system against the then common attack (in Europe) that in it, boys and girls mutually exploit each other. Dating is not such a hard system, he is reported to have said, but a positive means to initiate American youth into healthy sexuality and to promote a mature choice of partner. At this point, in accordance with prevalent Dutch public opinion which was still strongly against pre-marital sex, the Dutch reporter criticized Simpson, for he wrote: 'Prof. Simpson defends his value judgement of the significance of "dating" by referring to the Freudian theory that repression of normal desires until the authorised moment of marriage will always be harmful to that marriage. Initiation and preparation are to be appreciated as functional, that is, as positive.' It is in the context of this defence that Simpson was reported to have pointed to the large difference in the Netherlands between engaged and non-engaged couples, and he is quoted as having said: 'Engaged couples suddenly permit themselves a much larger freedom. Is then an engagement here indeed conceived of as a warranted bond for life?' He had a point, of course, but it offended the conservative Dutch who wanted to uphold the status façade. Over the decades, engagements had become increasingly sexualized, just like dating in the USA, but the sexuality in engagements was covered and set apart by the ideal of everlasting love. And it is quite telling that in this interview verkering was not mentioned at all.

Even Joke Smit, a somewhat insubordinate middle class girl, commonly credited with having triggered the second feminist wave in the Netherlands, ranged among those who tried to live up to the established ideal of restricting sex to an engagement, at least nominally. In the early 1950s, she and her friend Constant 
Kool had verkering, but on the day he arrived in Paris at the address where she stayed as an au pair and where they would share the same bed, they declared themselves to be engaged. They had often shared a bed before, but discretely, in private (Vuijsje 2008: 109). For doing this openly, they wanted the blessing consent derived from a declaration to be engaged.

\subsection{Gedogen: rekken en erbij blijven}

From 1939 up to the 1960s, each one of the twelve editions of a famous Dutch manners book contained advice on becoming engaged and on breaking off the engagement, but not on verkering or on courting and going out in the sense of dating; yet, in the tenth edition, published in 1953, this was added:

The young man who knows his world will pay a visit to the father of the girl he feels attracted to, after meeting her a couple of times, and ask his permission to take his daughter out now and then so they can get to know each other better. ... Most parents will appreciate this attitude: it prevents sneaky encounters and lies. (Groskamp-ten Have 1953: 25)

These words signal the rise of a new tradition of parents attempting 'to hang on' (erbij blijven) and to stay in the scene of their children.

By about 1960, this new tradition appears to have been established. On the one hand, it is called 'quite normal, also in circles where good manners are held in high esteem, that a girl is asked out by several young men without anyone disapprovingly saying that she 'has so many boys', for 'a girl is entitled to have male as well as female friends' (Palts-de Ridder and Eikhof ca 1960: 3). On the other hand, parents are advised to extend hospitality to all their children's proper friends, male and female, not expressly, but casually and lightly. In that way, the authors suggest, parents are able to keep an eye on their children and their ear close to the ground, thus allowing for at least some control over their contacts. And this policy of gedogen for the sake of erbij blijven (hanging on) was again recommended as the best way to prevent secret courtships at a far too early age (Palts-de Ridder and Eikhof ca 1960: 4).

In 1967, both gedogen and erbij blijven were amalgamated by the nationally beloved comedian Wim Sonnneveld as 'rekken en erbij blijven' (to stretch gedogen and (thus) remain in the scene). This happened in a sketch - 'as Dutch as the weather', his own words - in which a father on the day of his daughter's marriage addresses the audience about how he raised her as an equal, as a friend, adding that he himself never asked or told his parents anything, but did as he was told, and that his daughter as a modern child tells you everything but never does what you tell her. So when she brought home her first boyfriend, he did not tell her he didn't like him, but he praised the boy, he 'praised him straight to the grave', which became a Dutch expression [to some extent comparable to the English: 'he damned him with faint praise']. But other boyfriends came and they were all welcomed to the house and 
the dinner table, and this practice of 'rekken en erbij blijven' had served him to this day.

Rekken literally means to stretch or to prolong erbij blijven, and gedogen clearly is a necessary condition for practicing rekken. Rekken en erbij blijven became a well-known Dutch expression and its practice was and still is widely advocated as the best parental policy towards their courting children. Obviously, the practice also functioned to integrate the formal (adult) code and the informal (youth) code.

\subsection{The Expressive and the Sexual Revolution}

It was only in the Sexual Revolution that the social code prohibiting pre-marital sex was openly attacked and then soon eroded. 1968 saw the first national sexology survey (Kooij 1968): a majority of the Dutch population accepted practicing birth control, although they appeared to have little knowledge about it. Moreover, contraceptives could only be bought illegally or as a member of an Association. Half the population was in favour of rigorously forbidding contraceptives for unmarried people. This suggests that 1968 was at the end of a period of transition. Three years later, the legal ban of 1911 on the sale of contraceptives was lifted.

The next national survey of 1974 (Kooij 1976) shows that between 1968 and 1974, the Sexual Revolution had swept the Netherlands more rigorously than elsewhere. Unmarried living together had become accepted and the percentage of teenagers reporting to have full sexual experience had increased from 22 in 1968 to 40. ${ }^{3}$ Almost three in every four respondents said they would allow for pre-marital sex if the two 'are in love' (was 1 of 4 in 1968), and three of every five respondents would allow full sex if a young couple would 'feel strongly for each other' (was 1 in 5 in 1968). Parents had increasingly come to accept pre-marital sex of their teenage children, provided they have 'strong feelings for each other' and were 'ready for it', that is, ready for sex as an exploration of physical and personal feelings. On that basis, many parents would allow for petting (42\%) even at home (30\%). More than one in five parents (22\%) would consent to their teenager 'going all the way', provided they restricted themselves to one partner, while a little less than one in five parents (18\%) would allow that to happen at home (Boer 1979).

This means that in the years between 1968 and 1974 a trend in teenage sexuality appeared that would continue until today: 'feeling strongly for each other' would become the principal condition for having sex and also for a romantic and sexual sleepover. ${ }^{4}$ In the same period, the meaning of 'feeling strongly for each other'

\footnotetext{
${ }^{3}$ In 2005, 30\% of 12 to 19 year old youngsters reported full sex.

${ }^{4}$ In fact, already in the nineteenth century, 'feeling strongly for each other' was a major criterion for parents to consent to the sexual activity of their offspring. Two 'suitable
} 
changed significantly, because many teenagers now reported to have friends of the other gender. Learning to have a sexual relationship implied learning to have a relationship. In this process, the traditional observation that girls love boys more than sex, and boys love sex more than girls, had begun to erode. Both boys and girls liked 'being very close' and 'getting your partner excited' (Boer 1978: 144), indicating their longing for intimacy to be physical and relational. In 1989, this trend had continued to equality: as many schoolgirls as schoolboys mentioned relational intimacy and physical pleasure (both over $70 \%$ ) as a motive for having sex (Vogels \& Vliet 1990: 71).

In her book on teenage sexuality, Anita Ravesloot (1997) has presented a vivid picture of the changes over one generation. In the course of several years she asked the generation of 'youth of the 1980s', born between 1968 and 1972, about their sexual experiences and she also asked their parents, 'youth of the 1950s', born between 1938 and 1945, about when they were teenagers themselves. The difference between the two generations looms large. The parents were fully raised in the traditional hierarchy of a breadwinner and his subservient housewife and mother. Getting engaged, marry, have and raise children, and grow old together belonged to a natural order of things. The stories of the 1950s generation about their youth clearly voice how oppressive these relations were felt to be. On the rebound, as parents they allowed their offspring a large freedom, also in sexual matters. Ideals of equality had boomed and so had parental trust in the capacity for selfcontrol of youngsters, while 'rekken en erbij blijven' had become family practice. For teenagers this implied the possibility of growing towards having sex when a couple has 'strong feelings for each other' and mutually consent to be 'ready for it'.

\subsection{The social legacy of verloving and verkering}

In 1995, having 'strong feelings for each other' sufficed for three-quarters as a precondition for having sex (Brugman et al.), and this figure had increased to $80 \%$ in 2005 (Graaf et al). In a study comparing Dutch and American middle class families in the early 1990s, Amy Schalet found that 9 out of 10 Dutch parents mention these conditions for allowing their teenagers to have sex 'under their roof', whereas 9 out of 10 American parents would never allow this (2004, 2011). In 2010, a survey replication of Amy Schalet's study fully confirmed its results (Brugman et al. 2010). In 2003, a large-scale representative survey showed that $67 \%$ of Dutch teenagers between 12 and 18 were allowed to sleep with a girlfriend or boyfriend in their room in the parental home.

partners' needed to convincingly express these strong feelings for each other, not only to their parents but also to their parent's families. 
Such is the present-day social legacy of the emancipation of youth sexuality in the Netherlands. In its wake, the ritual of getting engaged lost most of its functions, and has virtually died off. Today, the word 'verkering' still smells bourgeois and is therefore in limited use, but in most ears 'verloven' (getting engaged) sounds pompous and outmoded. Some speak ironically of their fiancée (or fiancé) or of their 'steady friend', and there are many attempts at finding expressions that take at least some of the various stages of developments in their lust-balance and in sexual relations seriously whilst avoiding the stiff and rigid connotations of class, solemnity and hypocrisy. In a similar vein, the term 'puppy love' was dropped for being too belittling; this can be taken as another signal that to 'feel strongly for each other', to love and to make love are increasingly perceived as learning processes of which all stages are taken seriously. In this moment of transition, every phase in the development towards a more gratifying lust-balance has gained importance, thus stamping the term 'puppy love' out of fashion, but before a couple decides to get married, none of the phases are felt to be formally, that is, ostentatiously important, thus kicking the life out of the old ritual of getting engaged.

\section{A theoretical view on manners books and the functions of 'good society'}

In order to answer the question why this swing from formal and conservative to liberal and informal was so fast and pervasive in the Netherlands and rather lacking or lagging behind in the USA, attention to the connection between manners books as sources and the functions of 'good society' is needed. My main sources, in this article as well as in my studies Sex and Manners and Informalization, are manners books. They are a genre that existed throughout the research period (and long before). Therefore, these books can be systematically studied over a long period. The authors of these books try to capture the sensibilities, practices and ideals that reflect the dominant codes, and to sell this knowledge to insecure social climbers. It can only become profitably exploited (published and sold) if they convincingly address people who identify with the established in good society and aspire to acceptance in their group.

At the beginning of the twentieth century, it would not be wise to generalize the codes of good society, as formulated in manners books, to more than a small percentage of the total population - but that small percentage was dominant. The people in the dominant centres of power cherish and defend this code, which means that unless aspiring people adopt them, there is little or no chance for upward social mobility and social success. This is why authors and readers of manners books will identify with the established, and direct themselves by the code of good society, paying at least lip service to it. When whole new groups seek emancipation and become integrated, however, or when the balance of power in a society changes in other ways, the code as well as this lip service change.

In the course of the twentieth century, the public who read manners books expanded. Authors came increasingly to direct themselves to wider middle-class 
and 'respectable' working-class circles, and thus manners books as well as good society came to represent growing numbers of people from more and more layers of society. Thus, these books reflect the rise in the level of social integration. Even though at any particular moment these data are restricted to the strata of people identifying with the established classes and their good society, the study of changes in manners books opens a specific window on the rising level of social integration (Wouters 2007).

Within each society, the dominant code of manners and self-regulation is derived from sociability within the centres of power and their good society, that is, the circles of social acquaintance among people of families who belong to the centres of power, and who take part in their sociable gatherings, such as dinners and parties. Good societies and their codes have three functions: 1) a modelling function, 2) a representational function, and 3) a function to regulate social mobility and status competition. These three functions are also operative at lower levels of good society, further down the social ladder, or in the country or provinces (Elias 2012, Wouters 2007).

1) As the codes of good society are decisive in making friends and acquaintances, for winning a desirable spouse, and for gaining influence and recognition, they serve as a model for all socially aspiring people - they have a modelling function. Until the nineteenth century, courts had this function. In comparison with court circles, later circles of good society were larger, and sociability in them was more private, which made the modelling function of good society less visible. The dominant definition of proper ways to establish and maintain relations, however, remained constructed in these circles (or their functional equivalents among lower social strata).

2) At any time, the manners prevalent in good society tend to reflect the balance of power and dependence between established groups and outsider groups in society at large. As increasing layers of a society become emancipated and more socially integrated, the social codes of good societies come to represent these layers - they have a representational function. The code of a good society tends to spare the sensibilities of all groups represented in them; it reflects and represents the power balance between all those groups and strata that are integrated in society at large.

3) Thus the codes of good society also function to regulate social mobility and status competition. Their regime of manners not only regulates sociability, but also functions as a more or less refined system of inclusion and exclusion, an instrument to screen newcomers seeking entry into the higher circles of good society, thus helping to identify and exclude undesirables and ensuring that the newly introduced would assimilate to the prevailing regime of manners and self-regulation. In many countries of the nineteenth-century 'West', an increasingly formalized regime of manners, consisting of a complicated system of introductions, invitations, calls, leaving calling cards, 'at homes', receptions, dinners, and so on, had this function of regulating both entrance into good society and exclusion from it. 
As a rule, good societies are more compelling and effective in performing these three functions, the more they have closed their ranks at the top. It enables them to operate as a closed unity in regulating status competition and social mobility via the making and breaking of reputations. The more they are united, the more their social controls will extend through well oiled gossip channels to its various ranks and provinces.

This means that a 'good society' functions in different ways in different societies and at different stages of its development. A major difference between the USA and the Netherlands has been that in the USA, many competing good societies have remained in function, allowing people to seek entrance to a rival 'good society' or in a different state. In the Netherlands, good society was and has remained homogeneous enough to make that almost impossible.

\section{Explaining nationally different trajectories in regulating teenage sexuality}

As the codes of good society also involve the regulation of sexuality, including teenage sexuality, it seems obvious from this perspective to look for an explanation by comparing the structure of national power centres and the functioning of their good societies. The question is how and to what extent this comparison helps to explain national differences and characteristics?

\subsection{The regulation of social competition and of teenage sexuality in the Netherlands}

The compact smallness of the Netherlands allowed small-scale coteries as they were called, consisting of tight and overlapping networks with multifarious gossip channels spread over the whole country. They functioned like a cohesive good society, making and breaking reputations, regulating social mobility, and urging people to conformity to their code (Aerts and Velde 1998: 278). Accordingly, the tight and overlapping small-scale coteries of Dutch good society had a vigorous modeling function, a clear representational function, and it effectively functioned to regulate social competition and mobility.

The members of good society developed a solemn style of being deftig together with the liberal and sober stiffness of deftigheid. Closely related was a preoccupation with distinctions of stand, the word they preferred to class or rank; one did not consort with people of a lower stand. Until the mid1960s, the Dutch continued to use and also to discuss differences in stand more openly than in England and other European countries, where public discussions of these differences were tabooed earlier (Wouters 2007).

Nineteenth-century relations and manners lingered on longer in the Netherlands than in England, Germany or France. This points to the persistence of the typically Dutch pluralistic kind of state with negotiations at the top, prepared for by 
negotiations on lower levels of integration, and lots of commissions, committees and informal deliberations for doing preliminary work. Among the reasons for this to continue long into the twentieth century was a working class movement that, from its beginning, was rather strongly bourgeois-orientated.

Also important is the fact that the Netherlands did not participate in World War I. The Dutch ruling classes soon resumed control of the country according to pre-war codes. The typically Dutch verzuiling (pillarization), the rank and file support according to differences in religion also pressured towards conservatism, for the competition in loyalty to one's own zuil (pillar, denomination) boiled down to being submissively loyal to established authorities.

In this general cramp to stick to traditional codes and ideals, the Dutch increasingly resorted to keep up appearances, thus creating a façade of propriety and a widening gap between behavior in public and in private, particularly regarding sexuality. A significant case in point here is how the Dutch resorted to paying lip-service to the tradition of getting engaged and to keeping silent about verkering.

After World War II, representatives of the pre-war establishment, both progressives and conservatives, again aimed at restoration of the old order. Traditional hierarchy and deftigheid returned, although many of their sharpest edges were removed. At the same time, the gap between formal manners and informal practices rose to higher levels of hypocrisy, higher than in other countries.

This whole world vanished, so to speak, behind the smoke curtain from a smoke bomb pitched in 1966 at the royal carriage and parade for the wedding of Princess Beatrix and Prince Claus in Amsterdam. The metaphor of the smoke curtain conveys the success of the Dutch variant of an international youth and student protest movement in attacking stiff bourgeois culture: the whole world of deftigheid was washed away. Attacks at the hypocrisy in throwing a façade of propriety made this practice so unbearable that even the established joined the swift collective change: there was collective joy in moving away from hypocrisy. Old displays of standsbesef were now despised, and to call someone deftig was to brand him or her as a stiff and arrogant fossil from a world that had ceased to exist.

The swing of the pendulum went from manners that breathe hierarchy to manners that breathe equality. In the second half of the 1960s and throughout the 1970s, authority, etiquette, and rules in general remained suspect enough for manners books to become commercial flops: they were not published for more than fifteen years (Wouters 2007).

Leaving existing differences in habitus formation aside, the main reason why the clash of the generations and the Sexual Revolution had deeper and more lasting effects in the Netherlands was this gap of hypocrisy that had grown between a front stage of stiff pretence and backstage realities. If existing differences in habitus formation are taken into account, however, they help explain why the Dutch took a lead in several moral and legal respects. The old authorities and the new ones coming to power continued to take the issues of protest and individual rights seriously enough to set up committees, to negotiate and compromise (Kennedy 
1995). They joined the rapid and full swing from 'management by command' to 'management by negotiation' (Swaan 1990), and it is from the pervasion of this swing to the relation of parents and children that the swift change from 'no sex under my roof' to conditional 'sleepovers' can be explained.

This change towards a deeper commitment to negotiation and compromise than in most other countries implied a decline of social inequality. A necessary condition for this decline to occur was a relatively high level of social integration in the Netherlands in combination with a unified good society, functioning to cushion social competition and conflict. It provided a relatively high level of mutual trust allowing for a comparatively early legalization of marriage for homosexuals, of prostitution, abortion, euthanasia, soft drugs, and also paved the way for early conditional 'sleepovers' for teenagers. All these regulations expressed a relatively high level of mutually expected self-control, the issues at stake being neither to control nor to decontrol, but both: it was an attempt at controlled decontrolling, socially as well as individually (Wouters 2004, 2007).

\subsection{The regulation of social competition and of teenage sexuality in the USA}

One of the reasons why the switch from formal and conservative to liberal and informal was much slower and more restricted in the USA than in the Netherlands is that in the USA, gender inequality had hardened in the dating system. This inequality between women and men was connected with relatively unequal relations between parents and children. In my studies Sex and Manners and Informalization, I have tried to expound the explanatory power of America's relatively open competition between many good societies, and how this competitiveness has pervaded virtually all American manners and relations (see also Mennell 2007, Wouters 1998, 2011), including gender relations. It was replicated in a highly competitive dating system.

More open and fiercer social competition triggers higher status insecurity, which helps explain the development of more pronounced and accentuated forms of impression management such as boasting, the use of superlatives or overstatements and relatively open displays of feelings of superiority. These characteristic American manners, dating manners included, are symptomatic of uncertainty of rank, of porous and changing social dividing lines. In societies and circles where social competition and mobility are more clearly regulated and social positions less insecure, the use of superlatives tends to diminish. National characteristics such as a taste for understatement, self-mockery, and ridiculing or 'sending up' authority seem to have developed only in close connection to the development of a rather intense feeling of community with a relatively strong inhibition of anger, that is, in relatively cohesive and tightly-integrated societies.

The large variety of competing centers of power and their good societies also has explanatory power for the development of peer pressure as a part-process of the rise of the dating regime at colleges. The college campuses functioned as breeding 
ground for the development of peer pressure and allowed the young to form more of a united front in negotiations with parents and their representatives than young people in countries where parents were more united in enforcing the established codes. In the USA, as parents lacked a united good society, the young could use peer solidarity as a crowbar for change. The change in question was the establishment of the dating system at the colleges. At home, the dictum 'not under my roof' was maintained.

In the dating system, America's rather open competition and its weaker regulation of social mobility was reflected and simultaneously expressed in the words 'rating and dating'. These words indicate a regulation of teenage sexuality with rather instrumental and commercial attitudes towards sexuality in competitive relations. These types of attitudes and relations extended to 'paying and petting', thus probably providing a basis for an expanding consumption of sex and rising numbers of 'female chauvinist pigs'.

The question why the change from formal and conservative to liberal and informal was so fast and pervasive in the Netherlands and rather lacking or lagging behind in the USA can be answered also from the difference in welfare-state arrangements. Their relative lack in the USA indicates a lower level of social integration and also seems related to the 'American Dream' and its celebration of individual self-determination. To start the project of realizing this selfdetermination is not conceived of as compatible with still living at home with your parents and the same goes for having a full sexual relationship. At home, fathers' project and authority usually prevails. The Horatio-Alger type of individualism has entered the American habitus to the extent that the purposeful pursuit of individual ideals and ideas is experienced as an individual's inviolable right and thus, welfarestate arrangements are easily perceived as a threat and soon branded as 'socialism' or 'communism'.

In the Netherlands, a higher level of social integration and social solidarity was expressed in the spread of wealth via welfare-state arrangements. Since 1945, in a long period of peace and rising 'social and personal security', the arrangements of a caring welfare state have taken away many a sharp edge of status competition and created a 'peace' in material respects and a significant diminution of the fear of poverty. Increased wealth and the provision of 'social security' of a guaranteed minimum income by the state have been particularly important for women in relation to men - women becoming less dependent upon fathers and husbands - and for teenagers in relation to their parents. The state's alternatives provided a safety net that added to their strength in negotiations with husbands and fathers. In addition, student stipends and the strong rights position granted to minors made them less dependent upon their fathers' financial support (Wouters 1972). This generated a greater personal security and confidence, and on this basis, an ‘equanimity of the welfare state' blossomed (Stolk \& Wouters 1987; Wouters 1990), particularly in the period in which sexual sleepovers came to be accepted and spread. In comparison to their American counterparts, Dutch teenagers came to a position of relative equality in relation to their parents. This shift in the balance of 
power, a full swing from a 'management by command' to a 'management by negotiation', partly explains the changes in the Dutch regulation of teenage sexuality. An important addition to this explanation is the change in parenting styles coinciding with the shift in the power balance: relations between parents and children saw a decline in the level of suspicion and fear, and a rise in the level of mutually expected self-controls, that is, a rise of mutual trust.

\section{Concluding remarks}

In the Netherlands, until the 1960s, authors of manners books did not mention verkering, although this period of getting acquainted became a fairly general practice in between 1880 and the 1920s. Verkering counted as unrefined or vulgar and was not accepted by the upper classes. Identification with the established, who succeeded to keep a homogeneous good society functioning during many decades, largely explains why young people from families who belonged to good society or directed themselves to their code continued to celebrate the good-society tradition of getting engaged and kept the spread of verkering in the dark.

Dutch authors did not discuss verkering for probably the same reason as Mrs Post had avoided discussing petting: even mentioning them would provide dignity to informal, 'improper' and 'vulgar' practices that 'have no place in distinguished society'. This motive is corroborated by the fact that both American and Dutch upper class people looked down at these practices with disdain, and both verkering and dating have spread predominantly from the middle classes. This means that a large majority of Dutch authors have avoided mentioning verkering from the same motive as a minority of American authors have avoided mentioning petting: identification with the established. The difference is that the middle class peer group pressure behind the dating system was successful in getting the system integrated in the established national culture, whereas verkering in the Netherlands, although being a popular custom, retained its second-rate position, inferior to verloven (getting engaged). Most American authors followed the success of the dating system, most Dutch authors followed the success of their establishment and so did the Dutch population. But the depth of their identification with the established had weakened to the point where living up to the ideal of a getting formally engaged to be married was increasingly becoming a façade. Thus, whilst practicing verkering, the Dutch founded a tradition of paying lip-service to the tradition of the established.

Unlike their Dutch counterparts, American upper classes were unsuccessful in maintaining the dominance of their cultural tradition. Under the pressure of peer groups and middle classes, they were forced to climb down. Identification with the established shifted accordingly: establishing the dating system was experienced as liberation from an oppressive tradition. In the Netherlands, only the second half of the 1960s brought a similar experience. 
Apart from the different pace of the emancipation of sexuality, another major difference involves the lust balance. The word verkering refers to a relation and, both as a rule and as an ideal, relational intimacy - strong feelings for each other has remained at the heart and the origin of physical intimacy. In dating, sex was less embedded in love, it was less relational, for boys were allowed 'to get some' kissing, embracing and touching but only in transient relations that became increasingly instrumental and commercial, and only as a transitory phase from youth to adulthood, from the college boy and his flame (sex and pleasure) to the mature man and his sweetheart (love and responsibility).

This male-oriented formulation is now old-fashioned, of course, but it resulted from the boys-will-be-boys attitude, which has remained validity, although weakened. Boys becoming men have to change their lust balance from sexdominated to love-dominated, which in itself is difficult enough - not only for boys but also for girls, think of 'female chauvinist pigs' -, but due to the celebration of individual self-determination, most boys becoming men dream their wife to be loyal if not submissive to their project, and raise his children. Usually, his project of individual self-determination has priority above hers, and unless his project consists of being a father, most women may be equal at work, but not as a spouse or as a parent. In the Netherlands, as the traditional ideal lust-balance for both woman and men has consisted uninterruptedly of physical intimacy embedded in relational intimacy, women have had somewhat better chances of becoming increasingly equal, at work, as a spouse and as a parent. Teenagers have benefitted because increasing gender equality also opened up chances and motives for increasing equality between them and their parents.

The question why the Americans have held on to the tradition of pre-marital abstinence of sexuality and why the Dutch have invented and established a new tradition of allowing premarital sex, even at home, has been an intriguing and inspiring one. Of course, there are more relevant aspects for understanding, interpreting and explaining these differences than I have mentioned thus far. Yet, I hope, the presented description and comparison of the two national trajectories has at least hinted in the direction of an answer.

***

Many thanks to Stephen Mennell and Stephen Vertigans for comments and language improvements. 


\section{References}

A (1894) Doodgewone Dingen. Amsterdam: Centen.

Aerts, Remieg and Henk te Velde (eds) (1998) De stijl van de burger. Kampen: Kok.

Alsen, Ola (1936) Zoo zijn onze manieren. Een handleiding voor goede omgangsvormen. Leiden: Leidsche Uitgeversmaatschappij. (translated from the German)

Bailey, Beth L. (1988) From Front Porch to Back Seat: Courtship in TwentiethCentury America. Baltimore and London: John Hopkins University Press.

Boer, J. de (1978) Gevoelige kwesties omtrent seksuele kontakten van jongeren. Zeist: Nisso.

Boer, J. de (1979) Behoedzame Ontmoediging. Zeist: Nisso.

Brugman, Emily, Hans Goedhart, Ton Vogels, Gertjan van Zessen (1995) Jeugd en seks. Resultaten van het nationale scholierenonderzoek. Utrecht: SWP.

Brugman, Margaret, Sandra L. Caron, Jany Rademakers (2010) 'Emerging Adolescent Sexuality: A Comparison of American and Dutch College Women's Experiences', International Journal of Sexual Health 22/1: 32-46.

Brummell \& Co. (1927) De Man op z'n best. Een geestige Handleiding in SavoirVivre. Den Haag: Moorman.

Centraal Bureau voor de Statistiek (2003) Jeugd 2003, cijfers en feiten. Voorburg/Heerlen.

Cressey, Paul G. (1932) The Taxi-Dance Hall. A Sociological Study in Commercialized Recreation and City Life, New York: Ams Press, 1971, reprint of 1932, Chicago.

Caldwell, Mark (1999) A Short History of Rudeness. Manners, Morals, and Misbehaviors in Modern America. New York: Picador.

Curtin, Michael (1987) Propriety and Position. A Study of Victorian Manners. New York: Garland.

Davidoff, Leonore (1973) The Best Circles. Society, Etiquette and the Season. London: Croom Helm.

ECvdM (1911) Het wetboek van Mevrouw Etiquette voor Heeren in zestien artikelen, Utrecht: Honig.

ECvdM. (1912) Het wetboek van mevrouw Etiquette in 32 artikelen. Utrecht: Honig. 7 th ed.

Eggermont, Patricia (1993) Van houwen, trouwen (en berouwen). Informalisering rondom verloving, huwelijk en echtscheiding in Nederland, aan de hand van etiquettevoorschriften, 1850-1990. Doctoraalscriptie maatschappijgeschiedenis Erasmus Universiteit Rotterdam.

Eldridge, Elisabeth (1936) Co-Ediquette. Poise and Popularity for Every Girl, New York: Dutton.

Elias, Norbert (2012 [1939]) On the Process of Civilisation: Sociogenetic and Psychogenetic Investigations. Dublin: UCD Press [Collected Works. Vol. 3]. 
Engelberts, D.H. (1890) De goede toon. Een wegwijzer etc. Amsterdam/De Rijp: Van Raven.

Fass, Paula S. (1977) The Damned and the Beautiful. American Youth in the 1920s, New York: Oxford University Press.

Gorer, Geoffrey (1948) The American People. A study in national character, New York: Norton \& Co. (printed in 1959 as: The Americans: A Study in National Character. London: Arrow).

Graaf, Hanneke de, Suzanne Meijer, Jos Poelman, Ine Vanwesenbeeck (2005) Seks onder je $25^{e}$. Seksuele gezondheid van jongeren in Nederland anno 2005. Delft: Eburon.

Groskamp-ten Have, Amy (1939) Hoe Hoort Het Eigenlijk?Amsterdam: Becht. (13 ed: 1939; 4-5 ed: 1940; 6: 1941; 7: 1942; 8: 1947; 9: 1948; 10: 1953; 11: 1954; 12: 1957; 13: 1966).

Haeften, Olga van (1936) Manieren. Wenken voor wie zich correct willen gedragen. Amsterdam: Kosmos. (2nd ed. 1937, identical)

Hemphill, C. Dallett (1999) Bowing to Necessities. A History of Manners in America 1620-1860. Oxford UP.

Hochschild, Arlie Russell, with Anne Machung (1989) The Second Shift: Working Parents and the Revolution. New York: Viking Press.

Hochschild, Arlie Russell (1997) The Time Bind: When work becomes home and home becomes work. New York: Holt, Metropolitan Books

Jonathan, Norton Hughes (1938) Gentlemen Aren't Sissies, (A modern Guide Book for the Young Man About Town). Chicago: Winston.

Kennedy, James C. (1995) Nieuw Babylon in Aanbouw: Nederland in de Jaren Zestig. Amsterdam: Boom.

Kennedy, James C. (1997) 'New Babylon and the politics of modernity,' Sociologische Gids, XLIV: 361-74.

Kloos-Reyneke van Stuwe, Jeanne (1927) Gevoelsbeschaving. Rotterdam: Nijgh \& Van Ditmar.

Knap, Henri (1961) Zo zijn onze manieren. Amsterdam: Bezige Bij.

Kooy, G.A. (ed.) (1968) Sex in Nederland. Utrecht: Het Spectrum.

Kooy, G.A. (1976) Jongeren en seksualiteit. Sociologische analyse van een revolutionaire evolutie. Deventer: Van Loghum Slaterus.

Levy, Ariel (2005) Female Chauvinist Pigs: Woman and the Rise of Raunch Culture. New York: Free Press.

Margaretha, Anthonia (1921) Vormen en manieren. De eischen der Wellevendheid toegelicht voor onze Christelijke Kringen. Kampen: Kok.

McGinnis, Tom (1968) A Girl's Guide to Dating and Going Steady. Garden City NY: Doubleday.

Mead, Margaret (1950) Male and Female: A study of the sexes in a changing world. London: Gollancz; Part Four: The Two Sexes in Contemporary America.

Mennell, Stephen (2007) The American Civilizing Process. Cambridge: Polity

Paeuw, L. de (1934) Nette manieren. Een handboek der wellevendheid voor jong en oud. Baarle-Hertog: De Belgische Boekhandel (2nd ed). 
Palts-de Ridder, Yvonne and Vera Eikhof, (ca 1960) Hoe het "hoort". Van kennismaking tot huwelijk. Regina Goede Raad Serie Nr. 3, Haarlem: de Spaarnestad.

Pierce, Beatrice (1937) Etiquette for Young Moderns, Home Service Booklets.

Porter, Cecil (1972) Not Without A Chaperone: Modes and Manners from 1897 to 1914. London: New English Library.

Post, Emily (1922), Etiquette in Society, in Business, in Politics and at Home. New York: Funk and Wagnalls. (revised eds: 1923; 1927; 1931; 1934; 1937; 1942; $1950 ; 1960)$

Post, Toos (1938) Zoo Hoort Het. Wellevendheid als uiting van innerlijke beschaving en liefde tot den evenmensch. Utrecht: Urbi et Orbi (3e ed.)

Rappard, Jonkvr. H.A. (1912) Goede manieren. Wat men doen en laten moet in het dagelijksch leven. Haarlem: Visser, 3rd improved and enlarged edition. (1st: 1909, 2nd: 1910, 4th: 1920)

Ravesloot, Janita (1997) Seksualiteit in de jeugdfase vroeger en nu. Ouders en jongeren aan het woord. Amsterdam: Het Spinhuis.

Schalet, Amy Townsend (1994) 'Dramatiseren of normaliseren? De culturele constructie van tienerseksualiteit in de Verenigde Staten en Nederland', Amsterdams Sociologisch Tijdschrift 21 (2): 113-47.

Schalet, Amy Townsend (2003) Raging Hormones, Regulated Love: Adolescent Sexuality and the Constitution of the Modern Individual in the United States and the Netherlands. Dissertation. University of California, Berkeley.

Schalet, Amy (2004) 'Must we fear adolescent sexuality?: Not under my roof', Medscape General Medicine, 2004-1229. http://www.medscape.com/viewarticle/494933 8

Schalet, Amy (2011) Not Under My Roof: Parents, Teens, and the Culture of Sex. Chicago and London: Chicago University Press.

Schlesinger, Arthur M. (1946) Learning How to Behave: A Historical Study of American Etiquette Books. New York: Macmillan.

Schnabel, Paul (1998) 'Jeugd en seks', NRC Handelsblad 14-03-1998.

Schrijver, Elka (1954) Kleine gids voor goede manieren. Assen: Born. (reprints 1959, 1962)

Seidler, Dr. H.J. (circa 1911-15 ) Hoe men zich bij de heeren het best bemind kan maken. Rotterdam: Bolle.

Sonneveld, Wim (1967) Conference De Jongens (tekst: Simon Carmiggelt).

Staffe, Baronesse (1900s) Bestemming. Dochter, Echtgenoote, Moeder. vrij bewerkt naar het fransch door G.J Bakker Korff-Hoogeboom. Amsterdam: C.L.G. Veldt.

Stearns Peter N., and Mark Knapp (1992) 'Men and Romantic Love: Pinpointing a Twentieth-Century Change', Journal of Social History 26 (4): 769-95.

Stearns, Peter N. (1999) Battle Ground of Desire. The struggle for self-control in modern America. New York University Press.

Stolk, Bram van \& Cas Wouters (1987) Frauen im Zwiespalt. Frankfurt/M: Suhrkamp. 
Swaan, Abram de (1990) The Management of Normality. Critical Essays in Health and Welfare. London: Routledge.

Vanderbilt, Amy (1952) Amy Vanderbilt's Complete Book of Etiquette, A Guide to Gracious Living. New York: Doubleday 1952 (reprints 1958, 1963, 1972)

Veen-Wijers, Olga van (1936/40) Etiquette. Encyclopedie der correcte omgangsvormen. 's-Gravenhage: Succes. Universiteit voor zelfstudie. (19361940, also 1946-50)

Viroflay, Marguérite de (1916, 1919) Plichten en Vormen voor Beschaafde Menschen. Amsterdam: Cohen Zonen.

Vogels, A. \& R. van der Vliet (red.) (1990), Jeugd en seks. Gedrag en gezondheidsrisico's bij scholieren. SDU, Den Haag.

Vuijsje, Marja (2008) Joke Smit. Biografie van een feministe. Amsterdam: Atlas.

Wade, Margaret (1924) Social Usage in America, New York: Crowell.

Waller, Willard (1937) 'The Rating and Dating Complex,' American Sociological Review 2: 727-34.

Woude, Johanna van (1898) Vormen. Handboek voor dames. Amsterdam: Van Holkema en Warendorf.

Wouters, C. (1972) 'On Youth and Student Protest', Transactions of the Seventh World Congress of Sociology. Varna, September 14-19, 1970. Vol. III, Sofia: International Sociological Association: 197-205.

Wouters, Cas (1990) Van minnen en sterven. Informalisering van de omgangsvormen rond seks en dood. Amsterdam: Bakker.

Wouters, Cas (1998) 'Etiquette Books and Emotion Management in the Twentieth Century: American Habitus in International Comparison', in: Peter N. Stearns and Jan Lewis (eds.), An Emotional History of the United States, New York: NY UP, 283-304.

Wouters, Cas (2004) Sex and Manners. Female Emancipation in the West 1890 2000. London: Sage.

Wouters, Cas (2007) Informalization: Manners and Emotions since 1890. London: Sage.

Wouters, Cas (2011) 'Status Competition and the Development of an American Habitus' in: Christa Buschendorf, Astrid Franke, and Johannes Voelz (eds) Civilizing and Decivilizing Processes: Figurational Approaches to American Culture. Cambridge Scholars Publishing: 263-286. 